\title{
PELAYANAN KESEHATAN FISIOTERAPI LANJUT USIA MELALUI PEMERIKSAAN DAN PELATIHAN KESEIMBANGAN FLEKSIBILITAS SERTA KEKUATAN OTOT GENGGAM DI BANJAR KESIAN DESA LEBIH KABUPATEN GIANYAR
}

\author{
M.H.S. Nugraha ${ }^{1}$, N.L.P.G.K. Saraswati ${ }^{2}$, A.A.G.A.P. Negara $^{3}$, N.W. Tianing ${ }^{4}$
}

\begin{abstract}
ABSTRAK
Proses menua merupakan keadaan yang normal dan alamiah dan tidak dapat dihindari. Seiring dengan bertambahnya usia, maka terjadi penurunan kemampuan tubuh dalam melakukan aktivitas sehari-hari. Tujuan dari pengabdian masyarakat ini adalah untuk melakukan pengukuran serta pelatihan keseimbangan statis, fleksibilitas, dan kekuatan otot genggam. Pengabdian masyarakat dilakukan pada lansia di Banjar Kesian, Desa Lebih, Kabupaten Gianyar. Lansia yang ikut serta dalam pengabdian masyarakat ini berjumlah 40 orang yang terdiri dari: laki-laki sebanyak 12 orang dan perempuan sebanyak 28 orang. Pengukuran kekuatan otot genggam pada lansia masuk ke kategori rata-rata dan butuh peningkatan. Pengukuran keseimbangan statis masuk ke kategori baik dan butuh peningkatan. Sementara hasil pemeriksaan fleksibilitas termasuk ke kategori rata-rata dan di bawah rata-rata.
\end{abstract}

Kata kunci : fleksibilitas, kekuatan otot genggam, keseimbangan, pelatihan, pemeriksaan

\begin{abstract}
The aging process is a normal process that cannot be avoided. As we get older, there is a decrease in the body's ability to carry out daily activities. The aim of this community service is to measure and train static balance, flexibility, and handgrip strength. Community service is held on the elderly in Banjar Kesian, Lebih Village, Gianyar Regency. The elderly who participated in this community service were 40 people consist of: 12 men and 28 women. Measurement of handgrip strength in the elderly goes to the average and needs improvement category. The measurement of static balance is in the good and needs improvement category. While the results of the flexibility into the average and below average categories.
\end{abstract}

Keywords: assessment, balance, exercise, flexibility, handgrip strength

\section{PENDAHULUAN}

Indikator keberhasilan pembangunan di Indonesia dapat dilihat dari peningkatan Usia Harapan Hidup (UHH). Pada tahun 2000 persentase populasi lanjut usia mencapai 7,18\% dengan UHH 64,5 tahun. Peningkatan yang signifikan terlihat pada data survey tahun 2012, dimana persentase ratarata populasi lanjut usia di Indonesia mencapai 7,65\%. Provinsi Bali menjadi provinsi dengan rerata populasi lanjut usia yang telah melebihi angka nasional yaitu $9,78 \%$ sehingga menjadi peringkat ke-4 dengan jumlah lanjut usia terbanyak di Indonesia (Kemenkes, 2013). Berdasarkan

\footnotetext{
${ }^{1}$ Departemen Fisioterapi Fakultas Kedokteran Universitas Udayana, hendra_satria@unud.ac.id

2 Departemen Fisioterapi Fakultas Kedokteran Universitas Udayana, gitakarunia@unud.ac.id

${ }^{3}$ Departemen Fisioterapi Fakultas Kedokteran Universitas Udayana, anggapuspanegara@ unud.ac.id

${ }^{4}$ Departemen Biokimia Fakultas Kedokteran Universitas Udayana,wayan.tianing@unud.ac.id
} 
Pelayanan Kesehatan Fisioterapi Lanjut Usia Melalui Pemeriksaan dan Pelatihan Keseimbangan Fleksibilitas serta Kekuatan Otot Genggam di Banjar Kesian Desa Lebih Kabupaten Gianyar

klasifikasi World Health Organization (WHO) usia lansia dibagi ke dalam kelompok usia 45-59 tahun sebagai usia pertengahan (middle/young elderly), kelompok usia 60-74 tahun disebut sebagai lansia (elderly), kelompok usia 75-90 tahun disebut tua (old), dan usia di atas 90 tahun disebut sebagai sangat tua atau very old (WHO, 1989).

Proses menua merupakan keadaan yang normal dan alamiah dan tidak dapat dihindari. Faktor yang berkaitan dengan proses menua dapat dibagi menjadi dua, yaitu faktor internal dan eksternal. Faktor internal meliputi keadaan atau kondisi dari sistem musculoskeletal, kardiovaskular, saraf, pernafasan, dan ekskresi. Faktor eksternal berkaitan dengan pekerjaa, gaya hidup, dan faktor lingkungan. Kebiasaan seperti jarang melakukan aktivitas fisik, asupan nutrisi yang tidak baik, serta kurang tidur dapat menurunkan fungsi organ pada lansia (Rohana, 2011; Nugraha, et al., 2016).

Jatuh merupakan permasalahan utama yang sering dialami oleh lansia. Satu per tiga lansia yang berusia di atas 65 tahun, setiap tahunnya mengalami jatuh (British Columbia, 2004). Jatuh berkaitan dengan keseimbangan dan fleksibilitas tubuh yang kurang baik. Setiap tahunnya sekitar 13\% populasi lansia di AS mengalami kematian yang disebabkan oleh jatuh. Ketika lansia mengalami jatuh, maka akan kesulitan dalam melakukan aktivitas disertai penurunan rasa percaya diri, depresi, sampai merasa terisolasi secara sosial (Nugraha, et al., 2016; Josephson dan Rubenstein, 2006).

Permasalahan lainnya yang dihadapi oleh lansia adalah penurunan massa otot atau sarcopenia. Rekomendasi dari The European Working Group on Sarcopenia in Older People (EWGSOP) menyatakan bahwa penggunaan uji penurunan massa otot dan penurunan fungsi otot (kekuatan dan kinerja otot) pada lansia dapat digunakan dalam mendiagnosa sarcopenia. Kekuatan otot genggam tangan adalah teknik penilaian yang sederhana dalam menilai kekuatan otot. Genggaman tangan digunakan sebagai indeks kekuatan otot secara umum. Adapun faktor-faktor yang mempengaruhi kekuatan otot genggam pada lansia yaitu, dari segi demografi (usia, dan jenis kelamin), komposisi tubuh (tinggi, berat, densitas mineral tulang, ukuran tangan, lingkar lengan atas, tangan yang dominan digunakan), dari segi sosial ekonomi (pekerjaan, status sosial, gaya hidup) (Cruz-Jentoft, et al., 2010).

Dalam mengatasi permasalahan tersebut, dibutuhkan suatu bentuk pelatihan yang dapat meningkatkan keseimbangan, fleksibilitas, serta kekuatan otot genggam tangan. Pelatihan keseimbangan dilakukan melalui gerakan semi-tandem, full tandem, up on toes, serta one foot. Selain itu pelatihan keseimbangan lainnya yang dapat diberikan yaitu stepping in different directions dan reaching, serta walking tandem. Pelatihan fleksibilitas dilakukan melalui static stretching pada ekstremitas atas dan bawah selama 8 - 10 kali hitungan dan diulangi sebanyak 3 kali. Jenis pelatihan kekuatan otot genggam tangan yang dapat diberikan yaitu: hand gripper, squeezing resistance ball, elastic band, dan putty clay.

\section{METODE PELAKSANAAN}

Pelaksanan pelayanan kesehatan fisioterapi pada masyarakat dimulai pada tahap persiapan dengan melakukan kunjungan ke Banjar Kesian, Desa Lebih, Kabupaten Gianyar untuk melakukan perijinan, serta survey terkait dengan informasi awal yang diperlukan. Pada tahap ini, melibatkan beberapa staff dosen dan juga mahasiswa di Program Studi Sarjana Fisioterapi dan Profesi Fisioterapi FK Unud. Pada tahap ini, luaran yang diharapkan adalah terjalinnya kerja sama antara Program Studi Sarjana Fisioterapi dan Profesi Fisioterapi FK Unud dengan pihak Banjar Kesian, Desa Lebih, Kabupaten Gianyar serta terciptanya strategi pemecahan masalah terhadap tujuan pengabdian masyarakat yang akan dilakukan.

Pada tahap pelaksanaan, diawali dengan pemeriksaan terkait keseimbangan, fleksibilitas, serta kekuatan otot genggam. Setelah itu dilakukan pelatihan keseimbamngan, fleksibilitas, serta kekuatan otot genggam pada lansia. Berikut metode pelaksanaan kegiatan pengabdian masyarakat yang telah dilakukan:

\section{2 | BULETIN UDAYANA MENGABDI}


2.1 Pengukuran Resiko Jatuh pada Lansia

Pengukuran resiko jatuh pada lansia dilakukan dengan melaksanakan one leg standing test. Mekanisme pelaksanaan tes ini yaitu: lansia berdiri dengan salah satu kaki dominan dan kaki lainnya diangkat. Mata tetap terbuka dan mengarah ke depan. Pertahankan posisi ini selama yang bisa dipertahankan. Apabila tubuh sudah merasa goyang, maka catat waktu maksimal yang dapat dipertahankan (Michikawa, et al., 2009).

2.2 Pengukuran Fleksibilitas pada Lansia

Tujuan: Tes ini mengukur fleksibilitas tubuh pada ekstremitas bawah. Peralatan yang dibutuhkan: penggaris, kursi lipat, (tinggi sekitar 17 inci / $44 \mathrm{~cm}$ ). Prosedur: Subjek duduk di tepi kursi (diletakkan pada dinding untuk keselamatan). Satu kaki harus tetap menyentuh lantai. Kaki lainnya diluruskan ke depan dengan lutut ekstensi, tumit di lantai, dan pergelangan kaki ditekuk sebesar $90^{\circ}$. Letakkan satu tangan di atas tangan lainnya dengan ujung jari tengah yang rata. Instruksikan subjek untuk menarik nafas, dan kemudian saat mereka menghembuskan napas, menjangkau ke depan menuju jari kaki dengan menekuk di pinggul. Stabilisasi kepada dan penunggung untuk tetap lurus. Jaga lutut tetap lurus, dan tahan jangkauan selama 2 detik. Jarak diukur antara ujung ujung jari tangan dan ujung jari kaki. Jika ujung jari tangan menyentuh jari kaki maka nilainya adalah nol. Jika mereka tidak menyentuh, ukur jarak antara jari tangan dan jari kaki (skor negatif). Lakukan dua kali percobaan. Scoring: Skor dicatat hingga $1 / 2$ inci atau $1 \mathrm{~cm}$ terdekat saat jarak dicapai, baik skor negatif atau positif. Catat kaki mana yang digunakan untuk pengukuran. Di bawah ini adalah tabel yang menunjukkan kisaran yang direkomendasikan (dalam inci) untuk tes ini berdasarkan kelompok umur (Jones \& Rikli, 2002).

2.3 Pengukuran Kekuatan Otot Genggam pada Lansia

Subjek dikumpulkan dan dijelaskan mengenai prosedur pengukuran kekuatan otot genggam. Subjek diinstruksikan memegang handgrip dynamometer pada tangan dominan (tangan kanan). Subjek berdiri dan mengangkat bahu dan siku lurus keatas. Peneliti menginstruksikan untuk menggenggam handgrip sekuat mungkin. Test dilakukan sebanyak tiga kali, pada setiap sesi diberikan waktu istirahat 2 menit. Kemudian hasil terbaik dicatat.

2.4 Pelatihan Keseimbangan

Pelatihan 1: dilakukan melalui gerakan semi-tandem, full tandem, up on toes, serta one foot. Lakukan setiap gerakan dan ditahan selama 10 detik. Pelatihan 2: dilakukan melalui gerakan stepping in different directions dan reaching. Lakukan gerakan sebanyak 10 kali. Pelatihan Keseimbangan 3: dilakukan melalui walking tandem sejauh 3 meter.

2.5 Pelatihan Fleksibilitas

Pelatihan fleksibilitas dilakukan melalui static stretching pada ekstremitas atas dan bawah selama 8 - 10 kali hitungan dan diulangi sebanyak 3 kali.

2.6 Pelatihan Kekuatan Otot

Jenis pelatihan tahanan yang dapat diberikan yaitu: hand gripper, squeezing resistance ball, elastic band, dan putty clay. Pelatihan dilakukan selama 10 kali hitungan dan diulangi sebanyak tiga kali.

2.7 Evaluasi

Evaluasi dilakukan dengan melakukan post-test pengukuran resiko jatuh, fleksibilitas, dan kekuatan otot genggam pada lansia untuk mengetahui efek akut pelatihan. Selanjutnya evaluasi terkait program pelaksanaan pengabdian masyarakat dilakukan secara internal dengan melibatkan tim panitia dan pembantu lapangan. Evaluasi ekternal dilakukan dengan meminta saran kepada para lansia dan kepala lingkungan terkait pengabdian masyarakat yang telah dilakukan. Hasil evaluasi ditulis oleh notulen sebagai masukan perbaikan kegiatan ke depannya.

\section{HASIL DAN PEMBAHASAN}




\section{Pelayanan Kesehatan Fisioterapi Lanjut Usia Melalui Pemeriksaan dan Pelatihan Keseimbangan}

Fleksibilitas serta Kekuatan Otot Genggam di Banjar Kesian Desa Lebih Kabupaten Gianyar

Lansia yang ikut serta dalam pengabdian masyarakat ini berjumlah 40 orang yang terdiri dari: laki-laki sebanyak 12 orang dan perempuan sebanyak 28 orang. Berikut dipaparkan hasil pemeriksaan kekuatan otot genggam, keseimbangan statis, dan fleksibilitas.

Tabel 3.1. Hasil Pemeriksaan Kekuatan Otot Genggam

\begin{tabular}{ccc}
\hline Variabel & \multicolumn{2}{c}{ Kategori } \\
\cline { 2 - 3 } & Rata-rata & Butuh Peningkatan \\
\hline Laki-laki & 2 & 10 \\
Perempuan & 2 & 26 \\
\hline
\end{tabular}

Tabel 3.1 menunjukkan lansia laki-laki yang memiliki kekuatan otot genggam pada kategori rata-rata sebanyak 2 orang dan butuh peningkatan sebanyak 10 orang. Rentangan normatif untuk kategori rata-rata pada laki-laki yaitu $(36,5$ - 46), sementara untuk kategori butuh peningkatan yaitu (<36). Sedangkan lansia perempuan yang memiliki kekuatan otot genggam pada kategori rata-rata sebanyak 2 orang dan butuh peningkatan sebanyak 26 orang. Rentangan normatif untuk kategori rata-rata pada perempuan yaitu $(24,5-32)$, sementara untuk kategori butuh peningkatan yaitu $(<24)$.

Tabel 3.2. Hasil Pemeriksaan Keseimbangan Statis

\begin{tabular}{ccc}
\hline Variabel & \multicolumn{2}{c}{ Kategori } \\
\cline { 2 - 3 } & Baik & Butuh Peningkatan \\
\hline Laki-laki & 5 & 7 \\
Perempuan & 14 & 14 \\
\hline
\end{tabular}

Tabel 3.2 menunjukkan lansia laki-laki yang memiliki keseimbangan statis pada kategori baik sebanyak 5 orang dan butuh peningkatan sebanyak 7 orang. Rentangan normatif untuk kategori baik pada laki-laki yaitu (di atas 33 detik), sementara untuk kategori butuh peningkatan yaitu (di bawah 33 detik). Sedangkan lansia perempuan yang memiliki keseimbangan statis pada kategori baik sebanyak 14 orang dan butuh peningkatan sebanyak 14 orang. Rentangan normatif untuk kategori baik pada perempuan yaitu (di atas 30 detik), sementara untuk kategori butuh peningkatan yaitu (di bawah 30 detik).

Tabel 3.3. Hasil Pemeriksaan Fleksibilitas

\begin{tabular}{ccc}
\hline Variabel & \multicolumn{2}{c}{ Kategori } \\
\cline { 2 - 3 } & Rata-rata & Di bawah rata-rata \\
\hline Laki-laki & 12 & 0 \\
Perempuan & 27 & 1 \\
\hline
\end{tabular}

Tabel 3.3 menunjukkan lansia laki-laki yang memiliki fleksibilitas pada kategori rata-rata sebanyak 12 orang dan tidak ada yang masuk ke dalam kategori di bawah rata-rata. Rentangan normatif untuk kategori rata-rata pada laki-laki yaitu $(-2,5-4)$, sementara untuk kategori di bawah rata-rata yaitu $(<-2,5)$. Sedangkan lansia perempuan yang memiliki fleksibilitas pada kategori ratarata sebanyak 27 orang dan di bawah rata-rata sebanyak 1 orang. Rentangan normatif untuk kategori rata-rata pada perempuan yaitu $(-0,5-5)$, sementara untuk kategori di bawah rata-rata yaitu $(<-0,5)$.

Sebelum dilakukan pelayanan kesehatan berupa pelatihan keseimbangan, fleksibilitas sendi, dan kekuatan otot, akan dilakukan pemeriksaan terkait fungsi keseluruhan aspek tersebut. Keseimbangan berkaitan dengan resiko jatuh pada lansia. Pemeriksaan resiko jatuh diperiksa dengan menggunakan timed up and go test. Penelitian terdahulu membuktikan bahwa timed up and go test memiliki nilai interrater reliability yang tinggi yaitu: 0,91 (Nordin, et al., 2006); 0,99 (Hansen, et al., 1999); 0,99 (Creel et al., 2001). Systematic review dari (Beauchet et al., 2011) membuktikan bahwa terdapat hubungan antara timed up and go tets dengan resiko jatuh. Nilai cut off points yang ditetapkan dari 10 - 32,6 detik. Selain itu, pemeriksaan lainnya yang dapat digunakan untuk mengukur keseimbangan, khususnya keseimbangan statis yaitu melalui one leg 
standing test. Keseimbangan statis diperlukan untuk mempertahankan posisi tubuh ketika tubuh dalam keadaan diam seperti berdiri tegak ataupun duduk (Michikawa, et al., 2009).

Pengukuran fleksibilitas sendi pada lansia dilakukan dengan menggunakan Chair Sit and Reach Test (CSR). Penelitian (Jones, et al., 1998) menunjukkan bahwa CSR memiliki nilai interclass testretest reliability yang baik ( 0,92 pada laki-laki dan 0,96 pada subjek perempuan). Selanjutnya dilakukan pemeriksaan kekuatan otot menggunakan hand grip dynamometer. Kekuatan genggam otot tangan merupakan teknik penilaian yang sederhana yang direkomendasikan dalam menilai kekuatan otot oleh European Working Group on Sarcopenia in Older People (EWGSOP). Penelitian terdahulu menunjukkan bahwa pengukuran kekuatan otot dengan hand grip dynamometer memiliki nilai ICC 0,97 dimana didapatkan cut off point sebesar $28,5 \mathrm{~kg}$ pada lakilaki dan $18,5 \mathrm{~kg}$ pada subjek perempuan (Wang dan Chen, 2010).

Analisa gambaran pemecahan masalah, memperhatikan studi literature terdahulu dari peneliti sebelumnya, Critical appraisal pada penelitian Randomized Control Trial (RCT) dilakukan oleh penulis untuk mempertimbangkan intervensi pelatihan terbaik yang dapat diberikan pada pelayanan kesehatan ini. Systematic review yang dikemukakan oleh Horak (2006) dan metaanalisis Sibley et al (2015) menyimpulkan bahwa terdapat 6 komponen dasar penyusun sistem kontrol postural, meliputi: (1) Kendala biomekanik, terkait kekuatan otot dan limit of stability yaitu kemampuan seseorang dalam menggerakkan pusat gravitasi tubuh dan mengontrol keseimbangan tanpa mengubah bidang tumpu, (2) Strategi gerakan berupa feedback dan feedforward, (3) Strategi sensoris meliputi: sensory integration dan sensory re-weighting, yaitu kemampuan untuk meningkatkan bobot sensorik bergantung pada seberapa penting konteks sensori dalam menjaga stabilitas, (4) Orientasi ruang, yaitu kemampuan untuk mengarahkan bagian tubuh sehubungan dengan gravitasi, bidang tumpu, sistem visual, dan referensi internal, (5) Kontrol dinamik, dan (6) Proses kognitif terkait perhatian dan proses pembelajaran. Keseluruh konsep ini diadaptasi melalui pelatihan keseimbangan yang akan diberikan oleh lansia melalui pelatihan, sebagari berikut: (1) static balance stance (semi-tandem, full tandem, up on toes, dan one foot), (2) center of gravity shifts (stepping in different directions, reaching), (3) tandem walking (Nugraha, et al., 2016).

Pelatihan fleksibilitas diaplikasikan melalui peregangan statis pada otot-otot ekstremitas atas dan bawah. Penelitian dari (Paz et al., 2017) membuktikan bahwa peregangan statis yang diberikan pada lansai memberikan manfaat positif terhadap peningkatan fleksibilitas, keseimbangan, mobilitas, serta jumlah langkah per menit. Hal ini juga dipertegas melalui penelitian (Galo et al., 2012) yang menyatakan bahwa peregangan statis pada lansia memberikan efek positif terhadap peningkatan fleksibilitas, kekuatan otot, serta daya tahan aerobik. Penelitian lainnya oleh (Reddy dan Alahmari, 2016) menyatakan bahwa pelatihan peregangan pada ekstremitas atas meningkatkan keseimbangan setelah dievaluasi dengan single limb stance dan berg balance scale.

Peningkatan kekuatan otot genggam dapat dilatih dengan memberikan pelatihan resistance pada otot-otot yang bertanggung jawab terhadap hand grip. Jenis pelatihan tahanan yang dapat diberikan yaitu: hand gripper, squeezing resistance ball, elastic band, dan putty clay. Penelitian (Anandhi et al., 2017) menunjukkan bahwa pelatihan resistance exercise pada lansia dapat meningkatkan kekuatan otot genggam, meningkatkan komponen fungsi tangan yang dievaluasi melalui kuesioner Michigan Hand Outcome, serta meningkatkan fungsi activity daily living.

Berikut beberapa dokumentasi terkait pengabdian masyarakat yang telah dilakukan.

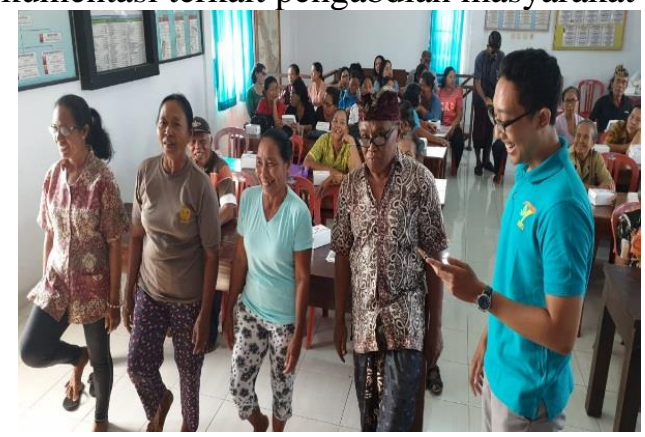

Gambar 3.1. Pemeriksaan keseimbangan statis 


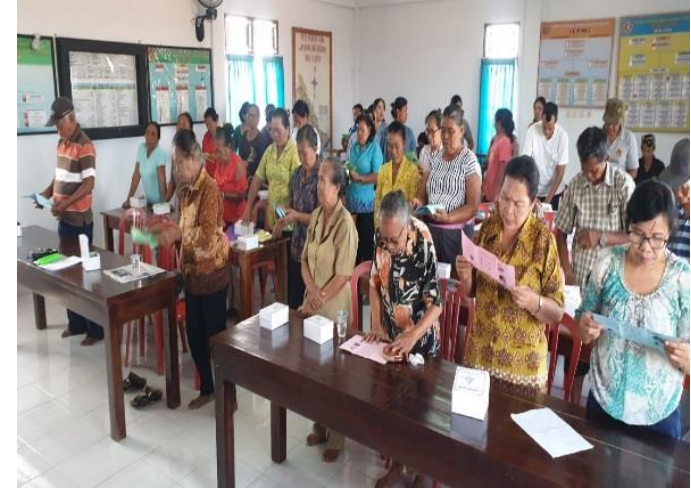

Gambar 3.2. Pembagian leaflet pelatihan keseimbangan, fleksibilitas, dan kekuatan otot genggam

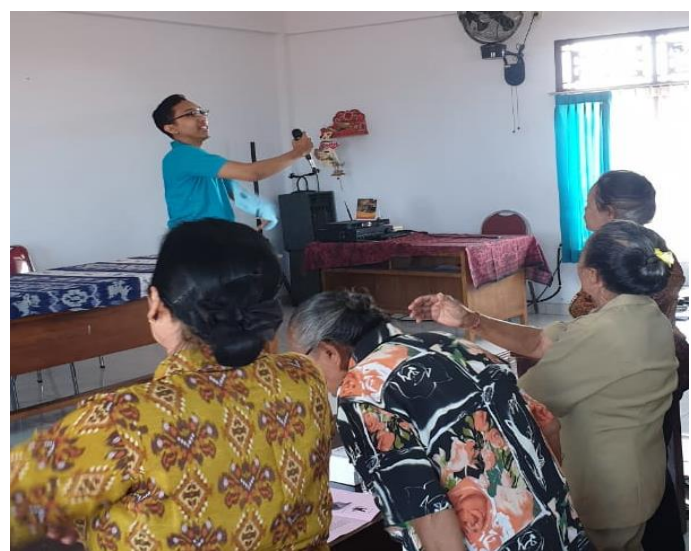

Gambar 3.3. Pelatihan fleksibilitas

\section{KESIMPULAN DAN SARAN}

Berdasarkan hasil dan pembahasan di atas, maka dapat disimpulkan bahwa:

1) Lansia yang ikut serta dalam pengabdian masyarakat ini berjumlah 40 orang yang terdiri dari: laki-laki sebanyak 12 orang dan perempuan sebanyak 28 orang.

2) Lansia laki-laki yang memiliki kekuatan otot genggam pada kategori rata-rata sebanyak 2 orang dan butuh peningkatan sebanyak 10 orang, sementara lansia perempuan yang memiliki kekuatan otot genggam pada kategori rata-rata sebanyak 2 orang dan butuh peningkatan sebanyak 26 orang.

3) Lansia laki-laki yang memiliki keseimbangan statis pada kategori baik sebanyak 5 orang dan butuh peningkatan sebanyak 7 orang, sementara lansia perempuan yang memiliki keseimbangan statis pada kategori baik sebanyak 14 orang dan butuh peningkatan sebanyak 14 orang.

4) Lansia laki-laki yang memiliki fleksibilitas pada kategori rata-rata sebanyak 12 orang dan tidak ada yang masuk ke dalam kategori di bawah rata-rata, sementara lansia perempuan yang memiliki fleksibilitas pada kategori rata-rata sebanyak 27 orang dan di bawah rata-rata sebanyak 1 orang.

\section{UCAPAN TERIMA KASIH}

Terima kasih penulis ucapkan kepada Unit Penelitian dan Pengabdian pada Masyarakat (UPPM) Fakultas Kedokteran Universitas Udayana atas hilirisasi hasil penelitian untuk meningkatkan pengetahuan kesehatan. 


\section{DAFTAR PUSTAKA}

Anandhi, D., Gokila, D, dan Sivakumar VPR. 2017. Comparison of Functional Tasks Exercise Versus Resistance Exercise to Improve Grip Strength and Hand Function in Elderly Population. Journal of Physiotherapy Research. Vol 2, No 1:5

Beauchet, O. Fantino, B. Allali, G. Muir, SW. Montero-Odasso, M. dan Annweiler, C. 2011. Timed Up and Go Test and Risk of Falls in Older Adults: A Systematic Review. J Nutr Health Aging

Creel, G., Light, K. \& Thigpen, M. 2001. Concurrent and construct validity of scores on the Timed Movement Battery. Physical Therapy, 81(2), 789-798

Cruz-Jentoft, AJ., Baeyens, JP., Bauer, JM., Boirie, Y., Cederholm, T., Landi, F., Martin, FC., Michel, JP., Rolland, Y., Schneider, SM., Topinková, E., Vandewoude, M., Zamboni, M. Sarcopenia: European Consensus on Definition and Diagnosis. Age and Ageing 2010; 39: 412-423

Fenderson. Claudia, B. dan Ling, WK. 2012. Pemeriksaan Neuromuskular. Jakarta: Erlangga Medical Series

Gallo, LH. Gonçalves, R. Gurjão, ALD. Prado, AKG. Ceccato, M. Filho, JCJ. Gobbi, S. 2012. Effect of Different Stretching Volumes on Functional Capacity in Elderly Women. Brazilian Journal of Kinanthropometry and Human Performance

Hansen, K., Mahoney, J. \& Palta, M. 1999. Risk factors for lack of recovery of ADL independence after hospital discharge. Journal of the American Geriatrics Society, 47(3), 360-365

Horak, FB. 2006. Postural Orientation and Equilibrium: What do We Need to Know About Neural Control of Balance to Prevent Falls?. Age and Ageing. 2: p 7-11

Jones C.J., Rikli R.E. 2002. Measuring functional fitness of older adults, The Journal on Active Aging, pp. 24-30

Jones, CJ., Rikli, RE., Max, J., dan Noffal, G. 1998. The Reliability and Validity of a Chair Sit-and-Reach Test as a Measure of Hamstring Flexibility in Older Adults. Research Quarterly for Exercise and Sport Vol. 69, No. 4, pp $338-343$

Josepshon, K dan Rubenstein, L. 2006. Falls and Their Prevention in Elderly People: What Does the Evidence Show?. North America: Elsevier Saunders, p 807 - 808

Kemenkes RI. 2013. Gambaran Kesehatan Lanjut Usia di Indonesia. Jakarta: Buletin Jendela Data dan Informasi Kesehatan

Michikawa, T., Nishiwaki, Y., Takebayashi, T., dan Toyama, Y. 2009. One-Leg Standing Test for Elderly Populations. J Orthop Sci. 14:675-685

Nordin,E.,Rosendahl,E.\&Lundin-Olsson, L. (2006). Timed "Up\&Go" test:Reliability in older people dependent in activities of daily living-Focus on cognitive state. Physical Therapy, 86(5), 646-655

Nugraha, MHS., Nila, W., Muliarta, IM. 2016. Pelatihan 12 Balance Exercise Lebih Meningkatkan Keseimbangan Dinamis Daripada Balance Strategy Exercise pada Lansia di Banjar Bumi Shanti, Desa Dauh Puri Kelod, Kecamatan Denpasar Barat. Majalah Ilmiah Fisioterapi Indonesia 4(1)

Paz, CBD. Rossetin, LL. Correa, CL. Gomes, ARS. 2018. Comparison of Two Stretching Techniques on The Balance and Mobility of Older Women. Cad. Bras. Ter. Ocup., São Carlos, v. 26, n. 1, p. 27-34, 2018

Reddy, RS dan Alahmari KA. 2016. Effect of Lower Extremity Stretching Exercises on Balance in Geriatric Population. International Journal of Health Sciences, Qassim University, Vol 10, No 3

Rohana, S. 2011. Senam Vitalisasi Otak Lebih Meningkatkan Fungsi Kognitif Kelompok Lansia daripada Senam Lansia di Balai Perlindungan Sosial Propinsi Banten. Denpasar: Universitas Udayana

Sibley, K. Beauchamp, M. Ooteghem, K. Straus, S. dan Jaglal, S. 2015. Using the System Framework for Postural Control to Analyze the Components of Balance Evaluated in Standardized Balance Measures: A Scoping Review. American Congress of Rehabilitation Medicine. 96: p 122-132

Undang-Undang Republik Indonesia No. 13 Tahun 1998 Tentang Kesejahteraan Lanjut Usia

Wang CY dan Chen LY. 2010. Grip Strength in OIder Adults: Test-Retest Reliability and Cutoff for Subjective Weakness of Using the Hands in Heavy Tasks. Arch Phys Med Rehabil, Vol 91

WHO. 1989. Health of Elderly. Geneva: WHO 